\title{
BETWEEN NATURALISM AND THEISM: JOHNSTON AND PUTNAM ON THE REALITY OF GOD
}

\section{MAGNUS SCHLETTE}

FEST Heidelberg

\begin{abstract}
The essay compares Mark Johnston's and Hilary Putnam's approaches to the philosophy of religion in the framework of Charles Taylor's claim that in modernity 'intermediate positions' between theism and naturalism become increasingly attractive for a growing amount of people. Both authors show that intermediate positions between naturalism and theism are conceptually plausible without having to deny that the conflicting worldviews are about a mind-independent reality. Johnston bridges the gap between naturalism and theism by developing a panentheistic worldview, Putnam denies the necessity of bridging it by choosing an attitude toward the world that allows for the coexistence of at least partly incommensurable conceptualizations of what there is. In both cases the conceptual exploration of intermediate positions is fed by the authors' commitment to intellectual integrity in coming to terms with the tension between scientific explanation and religious interpretation in the age of applied sciences.
\end{abstract}

There is an obvious tension that has always qualified the relationship between natural explanation and religious interpretation of the world. The allegorical interpretation of authoritative religious scripture in the Jewish and Christian tradition, going back as far as Philo and Origines, has been at least partly motivated by this tension. Since the 1800 s, in the wake of Darwinism, historicism and the rise of empirical psychology, this tension is no longer a purely academic affair. It has deeply influenced the practical dispositions of a still growing majority of people. Even more so, it is the ubiquity of applied science in an increasingly technology-laden lifeworld that fosters this tension nowadays. The engineering force of technology reaches into the structure of life. If its organic constituents 
can be intentionally changed, it seems to be evident for many that they are also the essence of life. And the expanding scientific accessibility of the organic realm has consequences in habitus formation.

Two examples: Firstly, within the last 20 years the diagnosis of some sort of mental disorder has risen by over $30 \%$ in the Western world. The renowned psychiatrist Allen Frances has pointed out that the new Diagnostic and Statistical Manual of Mental Disorders, published in May 2013 (DSM-5) will cause a diagnostic inflation in psychiatry by reducing thresholds for existing disorders and introducing new disorders at the fuzzy boundaries to normality. ${ }^{1}$ Secondly, there is a growing market for braincare practices that promise to delay aging and prolong mental fitness. The prudential good of old age has been reformulated as a proper organic state that is under scientific control. In both cases, scientific explanation takes precedence over a change in the way of seeing one's own life. Comprehensive interpretations of life as they have been offered by religions seem to be dispensable in the light of a growing control over nature.

I suggest that under contemporary conditions in the West we should focus the tension between natural explanation and religious interpretation as 'cross-pressures' - to use Charles Taylor's term - between naturalism and theism. 'The great invention of the West', according to Taylor, is the establishment of 'an immanent order in Nature, whose working could be systematically understood and explained on its own terms, leaving open the question whether this whole order had a deeper significance, and whether, if it did, we should infer a transcendent Creator beyond it. This notion of the "immanent" involved denying - or at least isolating and problematizing - any form of interpenetration between the things of Nature, on the one hand, and the "supernatural" on the other.'2 Leaving open the question whether we should infer a transcendent Creator beyond the immanent order in Nature is, again, no academic question, but depends on the potential of the immanent order to do the whole job. The immanent order allows us to build hospitals, but does it get rid of sickness? It delivers the tools of prolonging one's life, but does it defeat mortality? It may increase material wealth, but does it secure happiness?

\footnotetext{
${ }^{1}$ Allen Frances, Saving Normal: An Insider's Revolt against Out-of-Control Psychiatric Diagnosis, DSM-5, Big Pharma, and the Medicalization of Ordinary Life (New York: HarperCollins Publishers, 2013).

${ }^{2}$ Charles Taylor, A Secular Age (Cambridge: Havard Univ. Press, 2007), p. 16.
} 
Taylor senses cross pressures in our culture 'between the draw of the narratives of closed immanence on the one hand, and the sense of their inadequacy on the other ${ }^{3}$ - the latter has obviously to do with the fact that the answers to the foregoing questions are negative. The Western population is torn between an anti-religious and particularly antiChristian sentiment that is based on the expanding knowledge gathered in the sciences and humanities on the one hand and an aversion toward some extreme form of reduction initiated by this very knowledge on the other. This reduction takes the 'nothing but' form: Sickness is nothing but a problem of proper medication; mortality will be rendered irrelevant by significantly extending our lifespan; consent on the vague topic of happiness can only be found in terms of the accessibility to material wealth.

But even those who sense the inadequacy of the immanent order are confronted with the cognitive problem of interrelating the immanent and the transcendent. Taylor's diagnosis is that late modernity unfolds a broad spectrum of 'intermediate positions' between naturalism and theism that tries to go beyond the 'nothing but'-stance toward the world, but at the same time does not fail to acknowledge that the immanent order is potentially coherent on its own terms. Therefore the intermediate positions don't go for any 'God of the gaps' like, for example, in certain theological interpretations of quantum mechanics. Obviously, the attempt of interrelating the immanent and the transcendent on these premises boils down to how we can conceptualize what is supposed to be real. The tension between naturalism and theism has an intrinsic drive to articulate itself within the dichotomy of realism vs. anti-realism. This dichotomy should be considered as indicating the striving for intellectual integrity in dealing with the cross pressures between naturalism and theism. In the following I will present two intermediate positions that both explicitly refer to intellectual integrity or honesty as the driving force of coming to terms with the aforesaid cross pressures in modern life. And both positions take, as I would say, intermediate positions between straightforward realism and anti-realism. These positions have been recently and prominently articulated by Mark Johnston in his contribution to philosophical theology under the title Saving God from 2009 and by Hilary Putnam in his reflections on the philosophy of religion since Renewing Philosophy and especially in Jewish Philosophy

3 Ibid., p. 595. 
as a Guide to Life, published in 2008. Before I suggest how Johnston and Putnam are to be located between realism and anti-realism, I intend to give a rough definition of the key terms I will be using.

The 'quest for reality' has a metaphysical and an epistemological side to it. I suggest calling metaphysically real that which is independent of what we think about it, and epistemically real what humans get to know in itself, in its mind-independent reality. ${ }^{4}$ Accordingly, metaphysical antirealism supposes that we cannot think of anything real as independent of our mind, whereas epistemic anti-realism rejects the possibility of knowing things in themselves. Various positions may be differentiated according to the relation of the metaphysical and the epistemic claim. It is possible to claim independence plus accessibility of certain entities, but also to combine the independence claim with the denial of accessibility to the supposedly independent. Whereas epistemic antirealism seems to follow necessarily from metaphysical antirealism, metaphysical realism does not force us to take the position of epistemic realism. We may think of a completely mind-independent world without expecting that we will ever come to a complete or even nearly complete conceptual account of this world. Let us see now, how naturalism and theism fit into the picture of the major dichotomy.

If we follow Arthur C. Danto's definition in The Encyclopedia of Philosophy, naturalism 'is a species of philosophical monism according to which whatever exists or happens is natural in the sense of being susceptible to explanation through methods, which, although paradigmatically exemplified in the natural sciences, are continuous from domain to domain of objects and events. Hence, naturalism is polemically defined as repudiating the view that there exists or could exist any entities or events which lie, in principle, beyond the scope of scientific explanation. ${ }^{5}$ I would rather refer to this position as scientism. It combines metaphysical realism with epistemic realism on the basis of scientific explanation. Other versions of naturalism would accordingly take science to deliver pragmatically successful explanations of the natural realm, explanations that might nonetheless radically change in the wake of scientific revolutions and their cultural embeddings.

${ }^{4}$ I follow Merold Westphal with this differentiation. Cf. Merold Westphal, 'Theological Anti-Realism', in Andrew Moore \& Michael Scott (eds.), Realism and Religion. Philosophical and Theological Perspectives (Aldershot: Ashgate, 2007), p. 132.

${ }^{5}$ Arthur C. Danto, 'Naturalism', in: The Encyclopedia of Philosophy (New York: Macmillan Publishers,1967). 
These versions would combine epistemic anti-realism either with metaphysical realism or metaphysical anti-realism. In the first case they would take the conceptual account of the natural realm as an ongoing process of approximation to theoretical coherence and consistency, which nevertheless might fail to grasp what the world is in itself. In the second case they would take the conceptualizations of the world as being somehow constitutive of what they intend to grasp.

How about theism? A metaphysically realist version of theism would contend that God has a mind-independent reality. Epistemic realism would additionally claim that this reality is subject to human knowledge, whether via reason or revelation. It is obvious that this position is at loggerheads with religious pluralism, since there can be only one veridical access to the mind-independent reality of God and accordingly the other ones must be false - unless they are taken to be different versions of the supposedly right access which can be correctly reformulated in the appropriate vocabulary. Metaphysically anti-realist conceptions of God take whatever his name refers to as being dependent on the cognitive faculties, desires and dispositions of man. One way to be metaphysically anti-realist about God would be to call him an imaginative construct. ${ }^{6}$ The supposed construct, again, calls for functional explanation. This position is compatible with a religion-critical as well as religion-affirmative stance. Justin Barrett, for example, a cognitive scientist at Oxford, claims that humans are 'naturally endowed with cognitive faculties that stimulate belief in the divine, ${ }^{7}$ including a hyperactive agent detection device. Whereas for Richard Dawkins this research feeds into his Darwinian account of religious belief that he takes to undermine its epistemic value, Barrett himself accepts it as evidence that can justify religious claims. ${ }^{8}$ Metaphysical realism about naturalism can very well coexist with metaphysical antirealism about theism, both, for unbelievers or even atheists as well as for believers.

${ }^{6}$ Cf. Gordon D. Kaufman, 'Mystery, God, and Constructivism', in Andrew Moore \& Michael Scott, op. cit., p. 16.

${ }^{7}$ Kelly James Clark and Justin L. Barrett, 'Reidian Religious Epistemology and the Cognitive Science of Religion', Journal of the American Academy of Religion, 79 (2011), pp. $639-675$.

8 The indication of this debate I owe to Wayne Proudfoot's 'Pragmatism and Naturalism in the Study of Religion', in Hermann Deuser, Hans Joas, Matthias Jung, Magnus Schlette (eds.), The Varieties of Transcendence: Pragmatism and the Theory of Religion (New York: Fordham Univ. Press, forthcoming). 
If we want to understand the cross pressures in our culture between realism and anti-realism about the worldviews of naturalism and theism we must understand how they contribute to the best account of our self-understanding. Consequently they must be viewed from the firstperson perspective. What speaks for realism in religious matters from the first-person-perspective is the fact that certain experiences we call religious are experiences about God, his action, presence and so forth. Even if those experiences might not be specific enough for a warrant of apprehension, believers are certain that they have encountered God and not, for example, his imaginative construct, which, by the way, cannot be the subject of an encounter for grammatical reasons: Nothing we just imagine can surprise or irritate us, and an encounter always bears the potential of an irritation or surprise. What that means in religious matters we may learn from the phenomenological precision of scholars in religious studies such as William James or Rudolf Otto. On the other hand, what speaks for anti-realism in religious matters is the fact that a realist interpretation of religious experience contradicts the suggestive force of our third-person-knowledge. Let me give you an example: ${ }^{9}$ the Swiss ethno-psychoanalyst Paul Parin once travelled to a Melanesian tribe and got to talk to members of this tribe. At some point he asked a young man how he contracted the suppuration of his right big toe. The man answered that his mother in law had bewitched him. A little later Parin noticed that the man's left big toe did not look much better. The man informed him that he got an infection there. Noticing that Parin was puzzled about his answer the man asked, whether he, Parin, did not know what an infection is. I bet we would have been puzzled too. We tend to think that whenever the story of infection is available to appropriately clarify a particular matter like a swollen foot, the story of witchcraft has lost its validity. There seems to be an expansive force in the naturalist worldview which invites the belief that, in the long run, it will be applicable to fields which so far have not been affected by it. Whenever a particular matter comes into the spotlight of the infection paradigm, it seems to force some sort of inferential scorekeeping on us that does not allow for the witchcraft paradigm anymore. What speaks for realism about naturalism, therefore, is the eminent success of science

\footnotetext{
${ }^{9}$ I owe this example to Hans Julius Schneider, 'Spirituelle Praxis, religiöse Rede und intellektuelle Redlichkeit', in Gerald Hartung \& Magnus Schlette (eds.), Religiosität und intellektuelle Redlichkeit (Tübingen: Mohr Siebeck, 2012).
} 
in establishing an order we may live by, an order with an enormous potential to manipulate and predict states and events. What speaks for an anti-realist stance about naturalism is the realm of experiences that science cannot account for, yet, unless it agrees to some form of descriptive reductionism.

As I already mentioned, a position mediating between realism and anti-realism could uphold that what there is, is independent of our minds, whereas our cognition of it does not just mirror it in itself but is contentually dependent on our conceptual activity. I now want to suggest that Mark Johnston - in Saving God from 2009 - and Hilary Putnam - in his later works on the philosophy of religion up to Jewish Philosophy as a Guide to Life from 2008 - offer two versions of how to take such an intermediate position in dealing with the tension between naturalism and theism. I will give a sketch of how they both digest the cross pressures of naturalism and theism, and then shortly comment on how their positions fit into the picture of the realism debate.

Let's start with Johnston's praise of naturalism. He understands 'legitimate naturalism' as 'proper respect for the methods and achievements of science, ${ }^{10}$ which means that theism receives its epistemic value from its coherence with the verification-related knowledge that has been acquired in the sciences. The achievements of science are treated as a benchmark for the credibility of religious convictions. On the other hand, Johnston defends these against scientism, proposed by 'undergraduate atheists' - as Johnston stresses the supposed simplicity of their worldview - according to which science 'will provide an exhaustive inventory of what there is. ${ }^{11}$ Johnston illustrates his route between a concept of theism that is indifferent to the achievements of science and a reductionist account of theism fuelled by scientism with a simple example: 'No one should think that an ordinary description of the neighbor's wedding and a mathematical description of the trajectories of the fundamental particles involved in the events of the wedding are descriptions of the very same activity, namely, the wedding. The physical events subsumed under the basic physical laws are thus better seen as the ultimate material constituents of the activities, achievements, and accomplishments whose forms physics has no business rehearsing.' ${ }^{12}$

\footnotetext{
${ }^{10}$ Mark Johnston, Saving God (Princeton: Princeton University Press, 2009), p. 43.

${ }^{11}$ Ibid., p. 47.

12 Ibid., p. 49.
} 
Accordingly Johnston suggests reflecting on the meaning of what there is according to theism in the light of the premise that it must consist of ultimate material constituents, which may be identified by science. 'Legitimate naturalism is not the thesis that only the natural realm exists. That is the thesis of scientism. Legitimate naturalism is the view that the domain of the natural sciences is complete on its own terms: every causal transaction ultimately consists of some utterly natural process, for example, mass-energy transfer. There are no gods of the gaps. ${ }^{\prime 3}$

The first step of this approach is the rigid refusal of supernatural elements and interpretations in the Christian tradition, which Johnston almost exclusively focuses on in his treatment of theism. Consequently, he understands 'God' not as a proper name, which according to his Kripke-style argumentation would have to be connected 'with a chain of reference that leads back to an original use of the name in question, a use in which the name was given to its bearer. ${ }^{14}$ The logic of his argumentation requires understanding 'god' as a descriptive name, since ' $t$ there is no original dubbing of someone or something as "God". ${ }^{15}$ Whereas proper names have a rigid reference, but flexible meaning, descriptive names to the contrary combine a flexible reference with rigid meanings: 'the reference of such names is just that of their semantically associated descriptions. ${ }^{\prime 16}$ In accordance with the monotheistic tradition he then specifies the content of this name as the 'Highest One from whom our salvation flows. For that is the common conception of God in the major monotheisms. ${ }^{17}$ Beware, now, that according to Johnston, the matrix of what there is consists of its ultimate material constituents. Hence his concept of God's existence, of his power and impact on the earthly matters has to match this naturalist premise, too. Johnston's solution that leans against an interpretation of the tetragrammaton, including a critical debate of traditional philosophical theology on this matter, is the conceptualization of god as 'the outpouring of Existence Itself by way of its exemplification in ordinary existents. ${ }^{18}$

Johnston then connects this ontological concept of God with an epistemological concept of religious experience as a form of direct

\footnotetext{
${ }^{13}$ Ibid., p. 127.

14 Ibid., p. 5.

${ }^{15}$ Ibid., p. 6.

16 Ibid., p. 7.

${ }^{17}$ Ibid., p. 13.

${ }^{18}$ Ibid., p. 113.
} 
realism that allows access to the self-disclosure of the Highest One in ordinary existents on condition of a revised way of seeing as well as a fundamentally changed attitude toward life. Here Johnston clearly borrows from Wittgenstein's lectures on ethics: 'In the experience of feeling absolutely safe, everything in one's sensory field is presented as a manifestation of something that remains the same despite its various transformations into things that come into being and pass away. Moreover, on the side of introspection or inner perception, one is given to oneself as just another such manifestation, one whose passing away will leave intact everything that is fundamentally precious. It is, if you like, an experience of ordinary existents as dependent aspects of something else, as modes or modifications of that something else, which itself always remains.' ${ }^{19}$ The point is that epistemology and ontology are intrinsically related: the self-disclosure of the Highest One ontologically encompasses its cognition, the cognition of the Highest One finds itself as being epistemically dependent on the self-disclosure of the Highest One. Johnston calls this 'presentationalism' in explicit opposition to the dogma of representationalism. ${ }^{20}$

But the accessibility of the Highest One calls for the virtue of selfdecentration, which Johnston takes to be at the core of the Gospel and the essence of grace and redemption. The large-scale defects of human life, personal suffering and individual striving for the sunny side of the street that intends to circumvent or at least buffer existential contingencies, are rendered irrelevant, the worldliness of self-love and righteousness are overcome. The believer devotes himself to the Highest One who provides salvation by disclosing himself in this very devotion that provides cognitive access to it. Johnston calls it agape, and Jesus Christ becomes his key symbol for this virtue: 'Christ conquers death on our behalf by ideally exemplifying agape, and stimulating it in us.. ${ }^{21}$ The image of Jesus Christ that Johnston evokes in Saving God is similar to Nietzsche's intimate portrait of Jesus as the 'Berg-, See - und WiesenPrediger, dessen Erscheinung wie ein Buddha auf einem sehr wenig indischen Boden anmutet.'.2 Johnston presents Jesus as the antetype of a panentheistic spirituality that enlivens the best of Christian theism.

\footnotetext{
19 Ibid., p. 111.

${ }^{20}$ Cf. ibid., p. 143.

${ }^{21}$ Ibid., p. 186.

${ }^{22}$ Friedrich Nietzsche, 'Antichrist', Götzendämmerung (Stuttgart: Kröner,1990), p. 227.
} 
Let's turn to Putnam, who embraces naturalism not less than Johnston does. In the autobiographical introduction to his Jewish Philosophy as a Guide to Life from 2008, he described his standpoint between naturalism and theism as 'somewhere between John Dewey in A Common Faith and Martin Buber. ${ }^{23}$ Dewey stands for a religiously open naturalism that has also been referred to as religious naturalism. ${ }^{24}$ Dewey insistently defended and actually personally demonstrated that it is possible to integrate strong naturalist convictions and a deeply religious attitude toward the world. Dewey acknowledges what Taylor now calls the experience of fullness at the heart of authentic religiousness. He stresses that nobody need fear that she lose access to this deeper dimension of life if she revokes her commitment to the supernaturalist contents of traditional religion. And he also says that nobody seeking this deeper dimension of life is necessarily forced into supernaturalist convictions. Dewey accounts for this promise by centring religiousness in religious experience and by conceptualizing religious experience in a merely formal way, according to which "religious" as a quality of experience signifies something that may belong to all [...] experiences' 25 - whether they are aesthetic, scientific, moral or political. He wants to mobilize religious experience as an innerworldy force that may be present in all we do and that may shape our accomplishments. ${ }^{26}$ It is the force of 'being conquered, vanquished, in our active nature by an ideal end; it signifies acknowledgement of its rightful claim over our desires and purposes ${ }^{27}$ that unifies the self and evokes a feeling of harmony with the universe. ${ }^{28}$ Dewey calls faith the unification of the self 'through allegiance to inclusive ideal ends, which imagination presents to us and to which the human will respond as worthy of controlling our desires and choices.'. ${ }^{29}$ Please note that the intentional object of faith is an ideal that as such has neither a mere subjective reality 'in mind' nor a substantive reality within some remote ontological sphere, but an operative reality 'in character, in personality and action. ${ }^{30}$

${ }^{23}$ Hilary Putnam, Jewish Philosophy as a Guide to Life (Bloomington: Indiana University Press, 2008), p. 5.

${ }^{24}$ Cf. J. A. Stone, Religious Naturalism Today. The Rebirth of a Forgotten Alternative (Albany: State University of New York Press, 2007).

${ }^{25}$ John Dewey, A Common Faith (New Haven: Yale University Press, 1934), p. 10.

${ }^{26}$ Ibid., p. 14.

27 Ibid., p. 20.

${ }^{28}$ Ibid., pp. $22 \mathrm{f}$.

${ }^{29}$ Ibid., p. 33. 
Supernaturalist beliefs do not fit into this picture. They are wrong, since naturalism has an astonishing career of verification behind it and in front of it, which steadily diminishes the sphere of supernaturalist propositions held to be true. ${ }^{31}$ Besides that, supernaturalist beliefs 'weaken and sap the force of the possibilities' 32 inherent in the common and natural relations of mankind. Now, Dewey does not only rebuff supernaturalism, he also identifies the traditional institutionalized religions with supernaturalism. Again, he does not plea for giving up the idea of 'God' but for avoiding 'misleading conceptions' of what this idea 'really' refers to: 'For there are forces in nature and society that generate and support the ideals. They are further unified by the action that gives them coherence and solidity. It is this active relationship between ideal and actual to which I would give the name "God"."33

Putnam proceeds on his way to reconcile the naturalist and the theistic outlook by accepting Dewey's general naturalist and religious premises, but declining the conclusions he draws from them: Supernaturalism is wrong, 'the kind of reality God has is the reality of an ideal, ${ }^{34}$ an ideal as objective as it can be in that it calls forth deeds of great courage and dedication. On the other hand, God is not just an ideal like any other. 'The traditional believer', says Putnam, '- and this is something I share with the traditional believer [...] - visualizes God as a supremely wise, kind, just person. ${ }^{35}$ Indeed, this believer may ask whether Dewey defends a rather distortingly deflated concept of religious experience which leaves out what is essential to it, namely that it is intrinsically related to a supremely wise, kind, just person as its internal object. ${ }^{36}$ The argument is not that any religious experience worthy of its name has to be the experience of a personal God. The argument is that particular religious experiences cannot be reformulated in non-theistic terms without avoiding - in Wayne Proudfoot's terms - descriptive reductionism. ${ }^{37}$ Accordingly,

${ }^{30}$ Ibid., p. 48.

${ }^{31}$ Ibid., p. 30.

32 Ibid., p. 27.

${ }^{33}$ Ibid., p. 51.

${ }^{34}$ Ibid., p. 101.

${ }^{35}$ Ibid., p. 102.

${ }^{36}$ For this argument cf. Richard Bernstein, 'Pragmatism's Common Faith', in Stuart Rosenbaum (ed.), Pragmatism and Religion (Chicago: University of Illinois Press, 2003), p. 135.

${ }^{37}$ Cf. Wayne Proudfoot, Religious Experience (Berkeley: University of California Pr., 1985). 
Putnam also refutes Dewey's suggestion that by defending theism you feed into the pockets of supernaturalism. For Putnam, naturalist theism is possible. You may decline supernaturalism and still deeply believe in God as a person who is supremely wise and, above all, kind and just to you. How can that be?

I think that Putnam wants to reconcile Dewey-style religious naturalism with theism by turning to the philosophy of Wittgenstein. For Putnam, Wittgenstein's laconic linguistic observations on the religious use of language hint to how a reconciliation of naturalism and theism might be possible, a reconciliation that takes both to be cognitively valid outlooks on the world. Let me concentrate on five brief points in his interpretation of Wittgenstein:

(1) The meaning of a linguistic expression depends on the inferential commitments we have when using this expression. This becomes clear if we take a look at the analogy Wittgenstein draws between an algorithm on the one hand and the inferential commitments we enter into by using the vocabulary of our language on the other. If somebody said that 2 plus 21 was 13, it would be inappropriate to accuse him of making a mistake; the difference to our way of adding numbers would be just too big. This brings us to the next point:

(2) There are different semantic frameworks that qualify what we are inferentially committed to, when we use the vocabulary of our ordinary language. Wittgenstein makes it clear 'that religious people do employ pictures, and that they draw certain consequences from them, but not the same consequences that we draw when we use similar pictures in other contexts. If I speak of my friend as having an eye, then normally I am prepared to say that he has an eyebrow, but when I speak of the Eye of God being upon me, I am not prepared to speak of the eyebrow of God. ${ }^{38}$ But it may be objected that these different contexts of use simply hint to the difference between literal and metaphorical meaning, which brings us to the third point:

(3) The semantic frameworks in question cannot be reduced to each other. In consequence this means that the differentiation between literal and metaphorical meaning can only be appropriately drawn from a standpoint within each framework. And whether something can be said in a non-pictorial manner can only be decided inside the semantic

${ }^{38}$ Hilary Putnam, Renewing Philosophy (Cambridge: Harvard University Press, 1992), p. 156. 
framework in question. Here Putnam agrees with Wittgenstein, who says there may be pictures 'at the root of all our thinking, ${ }^{39}$ which must therefore be respected. Criteria for applying a picture, which are external to the semantic framework in which the picture is used, including criteria to translate a picture into a certain literal meaning, may entirely distort what the speaker intended to say. They may force inferential commitments upon him, which are completely foreign to his outlook on life. This point, in short, boils down to the claim that there are outlooks on life that are relatively incommensurable, as Putnam says. But we have to consider what this means in the light of the fourth point:

(4) No outlook on life is absolutely incommensurable with another because they all, although differently, refer to one world. As Putnam puts it in 'The Question of Realism': '[...] we can think of our words and thoughts as having determinate reference to objects (when it is clear what sort of "objects" we are talking about and what vocabulary we are using); but there is no one fixed sense of "reference" involved. Accepting the ubiquity of conceptual relativity does not require us to deny that truth genuinely depends on the behaviour of things distant from the speaker, but the nature of the dependence changes as the kinds of language games we invent change. ${ }^{40}$ This statement, again, has to be seen in the context of the fifth point:

(5) Semantic frameworks of the aforesaid non-reductive kind have the 'human weight' - as Wittgenstein formulates it - of being intrinsically embedded in a form of life and therefore expressing practical differences they make in the exchange between the individual and his environment. Putnam interprets Wittgenstein's remark that we can only know whether a believer is using a particular picture by the consequences he does or does not draw including inferential semantic commitments as much as practical commitments.

Let us return to Putnam's statement that God, in being visualized 'as a supremely wise, kind, just person', is 'not an ideal of the same kind as Equality or Justice'. In the light of his understanding and adaptation of Wittgenstein, he makes the point that the meaning of the word 'God' as much as its reference is entirely internal to the particular religious

\footnotetext{
${ }^{39}$ Ludwig Wittgenstein, Culture and Value, ed. G. Hendrik v. Wright (Oxford: Basil Blackwell, 1998), p. 83. Cf. Hilary Putnam, 'Does Disquotational Theory Solve All Problems', in Hilary Putnam, Words and Life (Cambridge, Mass.: Harvard University Press, 1995), p. 277.

${ }^{40}$ Hilary Putnam, 'The Question of Realism', in Hilary Putnam, Words and Life, p. 309.
} 
life form which is substantiated and individualized by the texts, rituals and practices of the according religion. The reality of this religion, so to speak, is the life form that entails semantic and practical commitments, which decide what it means to get it right or wrong to be in connection with God. Any claim that the belief in 'God' as a supremely wise, kind, just person (including all inferential commitments implied in calling him wise, just and kind) cannot be meant literally because literally persons have intentional mental states, which are physically embodied and located in space and time, sums up to unfair play. The reason is that claims of this kind mean controlling the believer's understanding of what it is for the picture to have an application by an antecedently filled-in version of that very picture, a version that is external to the inferential and consequential commitments of leading the life of a believer.

Putnam's adaptation of Wittgenstein bridges the gap between his critical affirmation of Dewey's A Common Faith and his standpoint toward Martin Buber's I and Thou, which became one of the later Putnam's focal points in dealing with Jewish philosophy as a guide to life. In Buber's Ich und Du Putnam finds the best of what fascinated him in Dewey's and Wittgenstein's thoughts on religion. He finds the trust in enlivening the objective world with the spirit of our ideal strivings Buber's dictum that the spirit of encountering the world faithfully 'can permeate the It-world and change it', even transfigure the objective world 'to the point where it confronts and represents the you', resulting in a 'Weltleben der Verbundenheit', would not have failed either to impress Dewey or Wittgenstein, ${ }^{41}$ moreover the denial that theorizing about God brings us any nearer to an understanding of what it means to address him. Furthermore the conviction that cognizing God is not a question of clarifying assertability conditions of propositions in which God is held to exist or to do certain things, but rather of encouraging oneself to a leap of faith expressed in addressing him; finally that addressing God is an I-Thou-relation not reducible to some sort of an objectifying I-It-relation we have established in subduing the world to our rational control. Whether God is a person, does according to Buber not depend on whether the believer can describe what sort of person God is, but on whether he finds the right tone for addressing him. ${ }^{42}$

${ }^{41}$ Martin Buber, Ich und Du (Heidelberg: Lambert Schneider Verlag, 1962), p. 146. Cf. Hilary Putnam, 'What $I$ and Thou is really saying', in Hilary Putnam, Jewish Philosophy, p. 63.

${ }^{42}$ Cf. Hilary Putnam, 'What $I$ and Thou is really saying', p. 66. 
How do Johnston and Putnam fit into the picture of the realismdebate? Both take science to generate successful conceptualizations of a mind-independent reality. Nevertheless both also deny the possibility of getting to know things in themselves. In different ways both take the real to transcend our modes of access to it.

Whereas for Johnston our cognitive access to reality is part of the very process through which the real comes into being, Putnam accepts the intrinsic self-limitation of our conceptual faculties, which cannot be bypassed. This difference is deeply related to the way each of them thinks about theism. Johnston's naturalism is religiously charged, Putnam's isn't. Johnston synthesizes naturalism and theism in a form of panentheism, whereas Putnam keeps them apart. According to Johnston religion somehow deepens the naturalist outlook on life, according to Putnam it takes an alternative conceptual approach. To that effect, for Johnston the pictorial dimension of religiously used language is a source of error and misunderstanding (in as far as it contradicts the naturalist account of the world), for Putnam it is flesh to the bone. Johnston is forced to comb through the scripture and sort out what does not fit into the naturalist view; Putnam is exposed to the limits of context-dependent understandability.

Where does Johnston's naturalistic account of religion leave us on Taylor's 'intermediate positions' between traditional theism and modern naturalism as competing worldviews in a secular age? Johnston explicitly addresses young and intelligent readers who refuse to build their individual view of life on 'less than convincing authority'. This reader is invited to prove himself - and for himself - which ones of the biblical texts speak the language of 'spiritual materialism' and which ones express authentic belief. 'The spiritual materialist is unauthentic in his engagement with religion [...], precisely because he simply turns his ordinary unredeemed desires toward some supposedly spiritual realm. ${ }^{\text {.3 }}$ Much of the description of the Highest One in the three monotheisms 'is at best metaphor, allegory, a series of honorific titles, or a web of analogy.44 Since the biblical books were written by humans, they are exposed to their weaknesses from vanity over envy, envy-driven ambition, fear, resentment and superstition. This explains the many faces of idolatry, which the reader faces in the bible and in the theological tradition of

${ }^{43}$ Ibid., p. 16.

${ }^{44}$ Johnston, op. cit., p. 99. 
its interpretation. Idolatry, Johnston says, is based on intentions to take partial representations of God as his authentic embodiments; it consists of ignorance toward the demands of devotional self-decentration; it contains the invention of subjectively beneficiary Hinterwelten and an afterlife in them; it means the domestification of religious experience in favour of egocentric motives: 'Instead of God's appearing as the wholly other, the numinous One who transcends anything that we can master by way of our own efforts, he appears as a potential patron, a powerful ally whom we might win over to our side. ${ }^{35}$ Idolatrous projections of the insecurities associated with the patriarchal psychological structure of ancient Near Eastern tribal life ${ }^{\prime 46}$ range from episodic narratives like Christ's Ascension from the Mount of Olives ${ }^{47}$ to grand biblical narrations like the Apocalypse - which Johnston takes to derive from revengeful prejudices against non-believers. Authentic belief, to the contrary, 'is an orientation in which the Highest One comes into view, with salvific effect.' ${ }^{\prime 8}$ In sum: The intermediate position Johnston proposes results in radical individualism that denies the authority of canonical text corpora as well as religious communities, which are based on tradition: One might paraphrase Johnston's position - using Grace Davies' pertinent formulation in a rather different sense - as believing without belonging.

Putnam fits quit differently into Taylor's range of intermediate positions. With reference to Buber's Zwei Glaubensweisen we may conclude that Putnam defends a form of belonging without believing, 'believing' meant in terms of acknowledging supposed facts as opposed to trusting somebody even without sound reasons that might legitimate this trust. According to Buber, faith in this second mode of trust is something man discovers as belonging to a community, whereas faith in the other mode is something that qualifies the believer in his solitude, whose community with others is not already there but being constituted as an alliance of those who have converted to the acknowledgement of supposed facts. ${ }^{49}$ Putnam's approach is 'communitarian' in stressing a commonly shared praxis of articulating religious worldviews in their own language. This also seems to be the upshot of how Putnam has

\footnotetext{
${ }^{45}$ Ibid., p. 23.

46 Ibid., p. 63.

47 Ibid., p. 45.

48 Ibid.

${ }^{49}$ M. Buber, Zwei Glaubensweisen (Heidelberg: Lambert Schneider Verlag, 1994),
} pp. $11 \mathrm{ff}$ 
come to terms with his own religious commitment. In 1975 the older of Putnam's two sons announced that he wanted to have a bar mitzvah. Putnam, not belonging to a minyan, had nevertheless become acquainted with the Rabbi of one of the Jewish congregations around Harvard. 'So when I had to find a place for my son to have his bar mitzvah, I found it natural to go and talk to Rabbi Gold about the possibility of Samuel having the ceremony in the Worship and Study congregation. We agreed that my wife and I would come to services with Samuel for a year, and that he would study with a Jewish student [...] to prepare for the ceremony. Long before the year was over, the Jewish service and Jewish prayers had become an essential part of our lives, and Rabbi Gold continues to be our teacher and friend to this day. ${ }^{50}$

To sum up the result of my comparison between Putnam and Johnston: Both authors show that intermediate positions between naturalism and theism are conceptually plausible without having to deny that the conflicting worldviews are about a mind-independent reality. Johnston bridges the gap between naturalism and theism by developing a panentheistic worldview, Putnam denies the necessity of bridging it by choosing an attitude toward the world that allows for the coexistence of at least partly incommensurable conceptualizations of what there is. In both cases the conceptual exploration of intermediate positions is fed by the authors' commitment to intellectual integrity in coming to terms with the tension between scientific explanation and religious interpretation in the age of applied sciences.

Acknowledgment. This paper was originally presented in Mainz, Germany, at a conference for the Analytic Theology Project, generously funded by the John Templeton Foundation.

${ }^{50}$ Hilary Putnam, Jewish Philosophy, p. 2. 